\title{
Water Requirements and Irrigation Scheduling of Maize Crop using CROPWAT Model
}

\author{
Shakeel Ahmad Bhat ${ }^{1 *}$, B.A. Pandit ${ }^{1}$, J.N. Khan ${ }^{1}$, R. Kumar ${ }^{1}$ and Rehana Jan ${ }^{2}$ \\ ${ }^{1}$ Division of Agricultural Engineering, SKUAST Kashmir, India \\ ${ }^{2}$ Division of Soil Science SKUAST-K, India \\ *Corresponding author
}

\author{
A B S T R A C T
}

Ke y w o r d s
Irrigation
Management, Crop
Water Requirement,
CROPWAT, Optimal
Irrigation Scheduling.
Article Info
Accepted:
15 September 2017
Available Online:
10 November 2017

Due to overexploitation of available water resources, it has become very important to define appropriate strategies for planning, development and management of water resources of the country. The study aims to develop an optimal irrigation scheduling, to increase crop yield under water scarcity conditions. The crop water requirement was found to be $304 \mathrm{~mm}$ and irrigation requirement $288.2 \mathrm{~mm}$. On refilling soil to field capacity with irrigation at critical depletion, irrigate at a given ET crop reduction per stage and irrigate at fixed interval per stage at $70 \%$ field efficiency gave a yield reduction of about $0 \%, 14.9 \%$, $25.1 \%$ respectively. Irrigation should be done at the critical depletion to achieve $0 \%$ yield reduction of maize and maximum rainfall efficiency. The research shows that the irrigation management model can effectively and efficiently estimate the crop water requirements. The model, that calculates evapotranspiration and crop water requirements, allows the development of recommendations for improved irrigation practices, the planning of irrigation schedules under varying water supply conditions and yields reduction under various conditions.

\section{Introduction}

Increased water demand brought about by rapid population growth has created the necessity to increase food production through the expansion of irrigation and industrial production to meet basic human needs, The primary objective of irrigation is to apply water to maintain crop Evapotranspiration (ET) when precipitation is insufficient. Hess (2005) defined crop water requirements as the total water needed for evapotranspiration, from planting to harvest for a given crop in a specific climate regime, when adequate soil water is maintained by rainfall and/or irrigation so that it does not limit plant growth and crop yield. Irrigation technologies and irrigation scheduling may be adapted for more effective and rational uses of limited water supplies. CWR depend on climatic conditions, crop area and type, soil type, growing seasons and crop production frequencies (FAO, 2009; George et al., 2000). CROPWAT is one of the models that are being extensively used in the field of water management throughout the world which is designed by Smith (1991) of the Food Agricultural Organization (FAO). CROPWAT facilitates the estimation of the crop evapotranspiration, crop water requirements and irrigation schedule with different cropping patterns for irrigation planning (Kuo et al., 2006; Gowda et al., 
2013; George et al., 2000; Gouranga and Verma, 2005; Martyniak et al., 2006; Dechmi et al., 2003; Zhiming et al., 2007).

CROPWAT is a decision support system developed by the Land and Water Development Division of FAO for planning and management of irrigation. CROPWAT is meant as a practical tool to carry out standard calculations for reference evapotranspiration, crop water requirements and crop irrigation requirements, and more specifically the design and management of irrigation schemes. It allows the development of recommendations for improved irrigation practices, the planning of irrigation schedules under varying water supply conditions, and the assessment of production under rain fed conditions or deficit irrigation (FAO 1992). Water use requirement for same crop varies under different weather conditions. To achieve effective planning on water resources, accurate information is needed for crop water requirements, irrigation withdrawal as a function of crop, soil type and weather conditions. CROPWAT is a FAO model for irrigation management designed by Smith [17] which integrates data on climate, crop and soil to assess reference evapotranspiration (ETo), crop evapotranspiration (ETc) and irrigation water requirements.

\section{Materials and Methods}

\section{Model description and input data}

CROPWAT for Windows is a decision support system developed by the Land and Water Development Division of FAO, Italy with the assistance of the Institute of Irrigation and Development Studies of Southampton, UK and National Water Research Center, Egypt. The model carries out calculations for reference evapotranspiration, crop water requirements and irrigation requirements in order to develop irrigation schedules under various management conditions and scheme water supply. It allows the development of recommendations for improved irrigation practices, the planning of irrigation schedules and the assessment of production under rainfed conditions or deficit irrigation (Adriana et al., 1999). CROPWAT for Windows uses the FAO (1992) PenmanMonteith method for calculation reference crop evapotranspiration.

Climate data: Which was collected from the Agro- meteorological station SKUAST-K. These data include maximum and minimum temperature, humidity, wind speed and sun hours. These data are essential to calculate ETo. CROPWAT calculate radiation and ETo depending on climate data. A sample of computation of reference crop evapotranspiration, ETo by penman Monteith method shown in Figure 1.

Rain data: Rain data was also collected from the Agrometeorological station and applied in CROPWAT software to obtain effective rainfall. Figure 2 shows a sample of rain data with effective rainfall obtained.

Crop data: The software needs some information about maize crop. These information have been obtained from FAO manual 56 [1] for maize crop including crop name; planting date; harvest, crop coefficient, $\mathrm{Kc}$; rooting depth length of plant growth stages; critical depletion and yield response factor. Values of Kc, rooting depth also are taken from FAO manual [1], Figure 3 shows a crop data applied in this software.

Soil data: Soil type in this area is a silty clay loam according to [3]. The software needs some general soil data like total available soil moisture; maximum rain infiltration rate; maximum rooting depth; initial soil moisture depletion and initial available soil moisture. 
These information obtained from FAO manual 56[1]. Figure 4 shows the application of these information in the software.

\section{Results and Discussion}

The CROPWAT 8.0 was used to prepare the irrigation schedule for maize crop. The model predicted the daily, decadal as well as monthly crop water requirement at different growing stages of maize crop. The crop water requirement and irrigation requirement for the maize crop was found to be $304 \mathrm{~mm}$ and $288.2 \mathrm{~mm}$ respectively. Figure 5 shows the graph of CROP water Requirement and Irrigation requirement of maize crop. For the application of irrigation, the critical soil moisture depletion was considered at $100 \%$. From the results, it was found that the yield reduction will not occur at any growing stage with maximum rainfall efficiency as predicted with irrigation at $100 \%$ critical depletion and by refilling the soil to the field capacity (Table 3). The detailed results of total gross irrigation, total net irrigation, actual water use by crop and potential water use by crop is given in the Table 2. The rain efficiency of 66 $\%$ was found and by this efficiency, effective rainfall was found to be $10.5 \mathrm{~mm}$. The total net irrigation varied from the irrigation requirement due to change in effective rainfall efficiency. The Figure 6 showed the irrigation schedule pattern at $100 \%$ critical depletion.

Table.1 Daily and decadal ETc and irrigation requirement

\begin{tabular}{|l|c|c|c|c|c|c|c|}
\hline Month & Decade & Stage & Kc & ETc & ETc & Eff rain & Irr. Req. \\
\hline & & & coeff & $\mathrm{mm} /$ day & $\mathrm{mm} / \mathrm{dec}$ & $\mathrm{mm} / \mathrm{dec}$ & $\mathrm{mm} / \mathrm{dec}$ \\
\hline Jul & 2 & Init & 0.3 & 1.32 & 13.2 & 2.2 & 11 \\
\hline Jul & 3 & Deve & 0.3 & 1.25 & 13.8 & 2.1 & 11.6 \\
\hline Aug & 1 & Deve & 0.49 & 1.88 & 18.8 & 2 & 16.8 \\
\hline Aug & 2 & Deve & 0.77 & 2.78 & 27.8 & 1.9 & 25.9 \\
\hline Aug & 3 & Deve & 1.07 & 3.61 & 39.7 & 1.5 & 38.1 \\
\hline Sep & 1 & Mid & 1.29 & 4.05 & 40.5 & 1.1 & 39.4 \\
\hline Sep & 2 & Mid & 1.3 & 3.77 & 37.7 & 0.7 & 37 \\
\hline Sep & 3 & Mid & 1.3 & 3.38 & 33.8 & 0.8 & 33 \\
\hline Oct & 1 & Mid & 1.3 & 2.99 & 29.9 & 1 & 28.9 \\
\hline Oct & 2 & Late & 1.23 & 2.47 & 24.7 & 1 & 23.6 \\
\hline Oct & 3 & Late & 1 & 1.69 & 18.6 & 0.8 & 17.8 \\
\hline Nov & 1 & Late & 0.75 & 0.55 & 5.5 & 0.6 & 4.9 \\
\hline Nov & 2 & Late & 0.61 & 0.06 & 0.1 & 0.1 & 0.1 \\
\hline & & & & & 304 & 15.9 & 288.2 \\
\hline
\end{tabular}

Table.2 Total gross irrigation, total net irrigation and efficiency of rain

Totals

Total gross irrigation

Total net irrigation

Total irrigation losses

Actual water use by crop

Potential water use by crop

Efficiency irrigation schedule

Deficiency irrigation schedule

\begin{tabular}{lll}
$395.8 \mathrm{~mm}$ & Total rainfall & $15.9 \mathrm{~mm}$ \\
$277.1 \mathrm{~mm}$ & Effective rainfall & $10.5 \mathrm{~mm}$ \\
\hline $0 \mathrm{~mm}$ & Total rain loss & $5.4 \mathrm{~mm}$ \\
$304 \mathrm{~mm}$ & Moist deficit at harvest & $16.4 \mathrm{~mm}$ \\
\hline $304 \mathrm{~mm}$ & Actual irrigation requirement & $293.5 \mathrm{~mm}$ \\
\hline $100 \%$ & Efficiency rain & $66 \%$ \\
\hline $0 \%$ &
\end{tabular}


Table.3 Yield reduction at $100 \%$ of critical depletion

\begin{tabular}{|lllllr|}
\hline Yield reductions & & & & & \\
\hline Stage label & A & B & C & D & Season \\
\hline Reduction in ETc & 0 & 0 & 0 & 0 & $0 \%$ \\
\hline Yield response factor & 0.4 & 1 & 1.3 & 0.5 & 1.25 \\
\hline Yield reduction & 0 & 0 & 0 & 0 & $0 \%$ \\
\hline Cumulative yield reduction & 0 & 0 & 0 & 0 & $0 \%$ \\
\hline
\end{tabular}

Table.4 Comparison of Irrigation water requirements, yield reduction and cropping intensity for maize

\begin{tabular}{|l|l|l|}
\hline Parameter of comparison & No water stress & with water stress \\
\hline Total gross irrigation & $395.8 \mathrm{~mm}$ & $321.9 \mathrm{~mm}$ \\
\hline Total net irrigation & $277.1 \mathrm{~mm}$ & $225.3 \mathrm{~mm}$ \\
\hline Actual water use by crop & $304 \mathrm{~mm}$ & 242.9 \\
\hline Potential water use by crop & $304 \mathrm{~mm}$ & 304 \\
\hline Yield Reduction \% & $0 \%$ & $25.10 \%$ \\
\hline & & \\
\hline Timing & Irr. At $100 \%$ deplet. & Irrig. At fixed interval per stage \\
\hline & & (Interval in days: initial 7, \\
\hline & & development 7, mid 20, late 7) \\
\hline & & \\
\hline Application & Refill to $100 \%$ of field & Refill to 100 \% of field \\
\hline & capacity & \\
\hline & & \\
\hline Field efficiency: $(\%)$ & 70 & 70 \\
\hline & & \\
\hline CROPWATT 8.O & & \\
\hline
\end{tabular}

Fig.1 Climate file

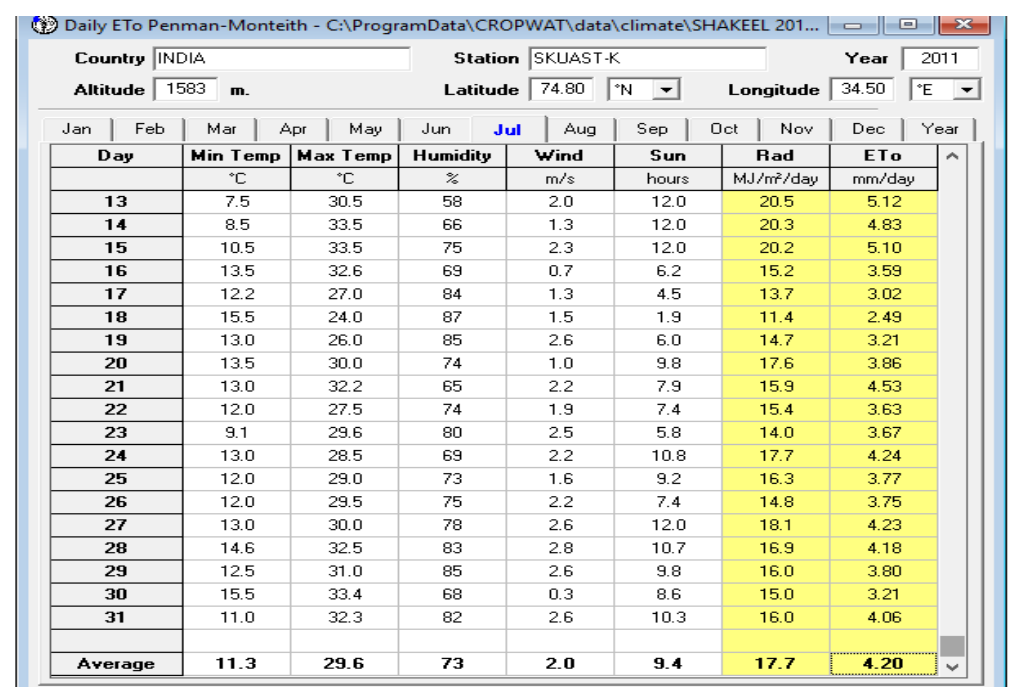


Fig.2 Rain file

\begin{tabular}{|c|c|c|c|c|}
\hline \multicolumn{2}{|c|}{ Station thalleny wingy } & \multicolumn{2}{|c|}{ Ell, tain method } & Fixed peicentage \\
\hline & & Rain & Ell rain & \\
\hline & & mm & mm & \\
\hline & January & 05 & 04 & \\
\hline & Fabruary & 89 & 7.1 & \\
\hline & Masch & 142 & 11.4 & \\
\hline & Aptil & 62 & 50 & \\
\hline & May & 21 & 1.7 & \\
\hline & Junt & 42 & 33 & \\
\hline & July & 65 & 52 & \\
\hline & Auqust & 56 & 45 & \\
\hline & 5 seplember & 25 & 20 & \\
\hline & Detobei & 30 & 24 & \\
\hline & Nowember & 1.3 & 1,0 & \\
\hline & December & 07 & $0 \overline{6}$ & \\
\hline & Total & 557 & 445 & \\
\hline
\end{tabular}

Fig.3 Crop file

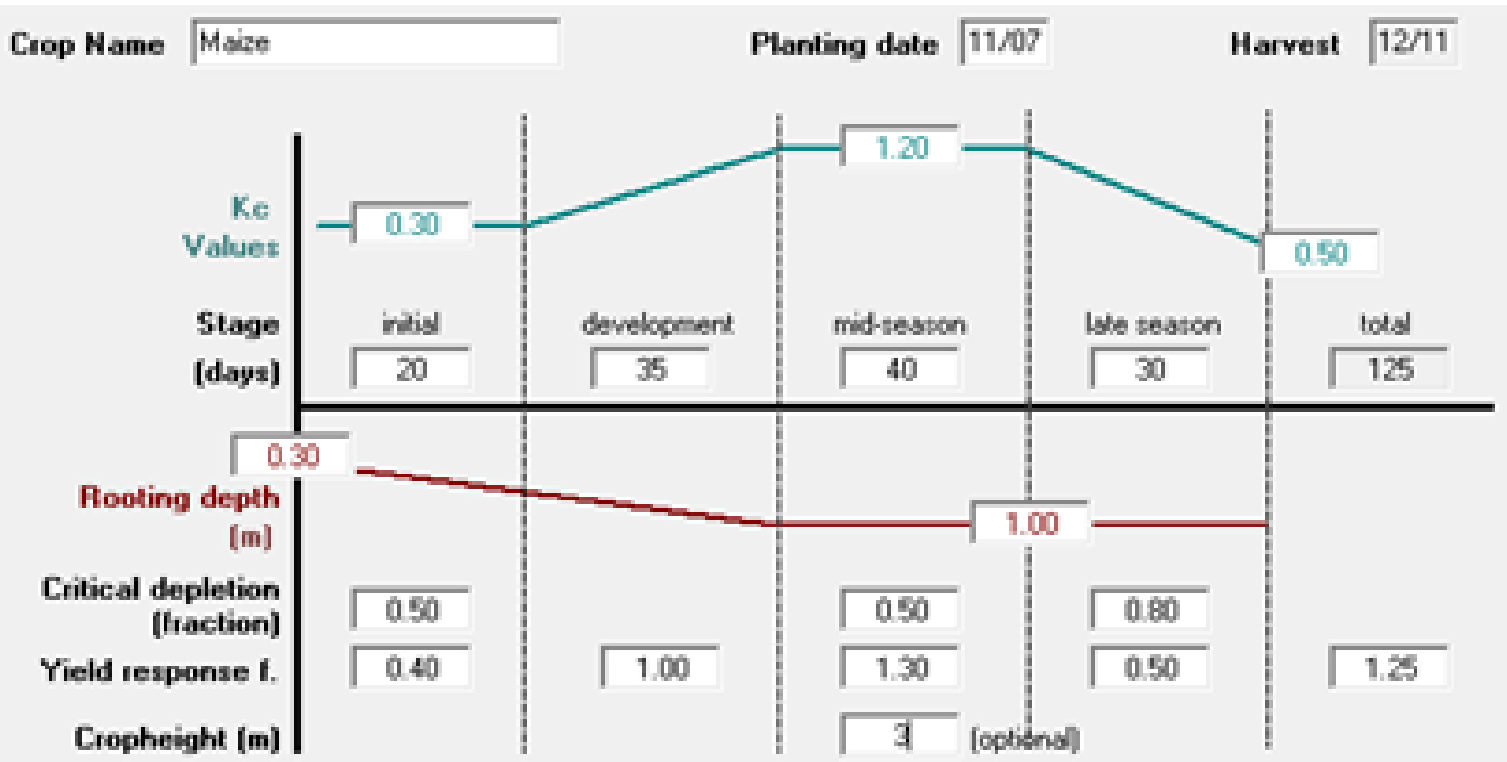


Fig.4 Soil file

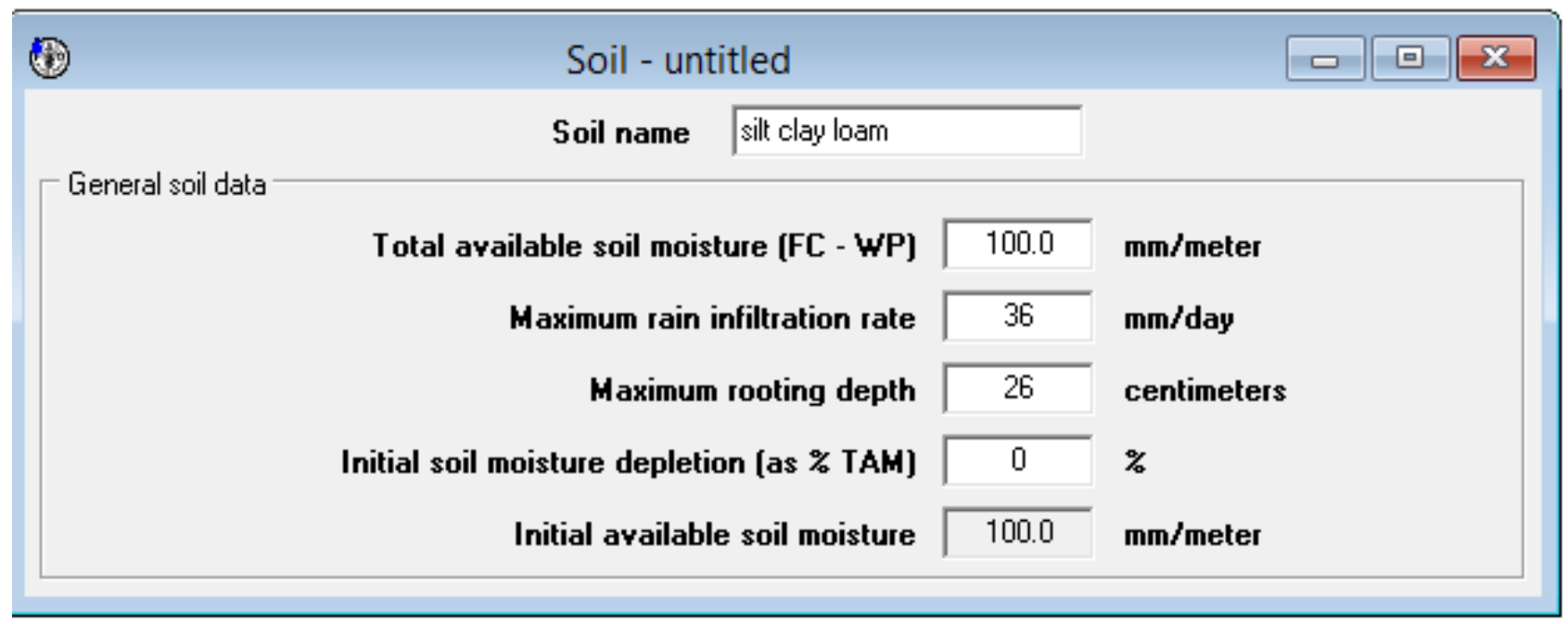

Fig.5 CROP water requirement and irrigation requirement of maize crop

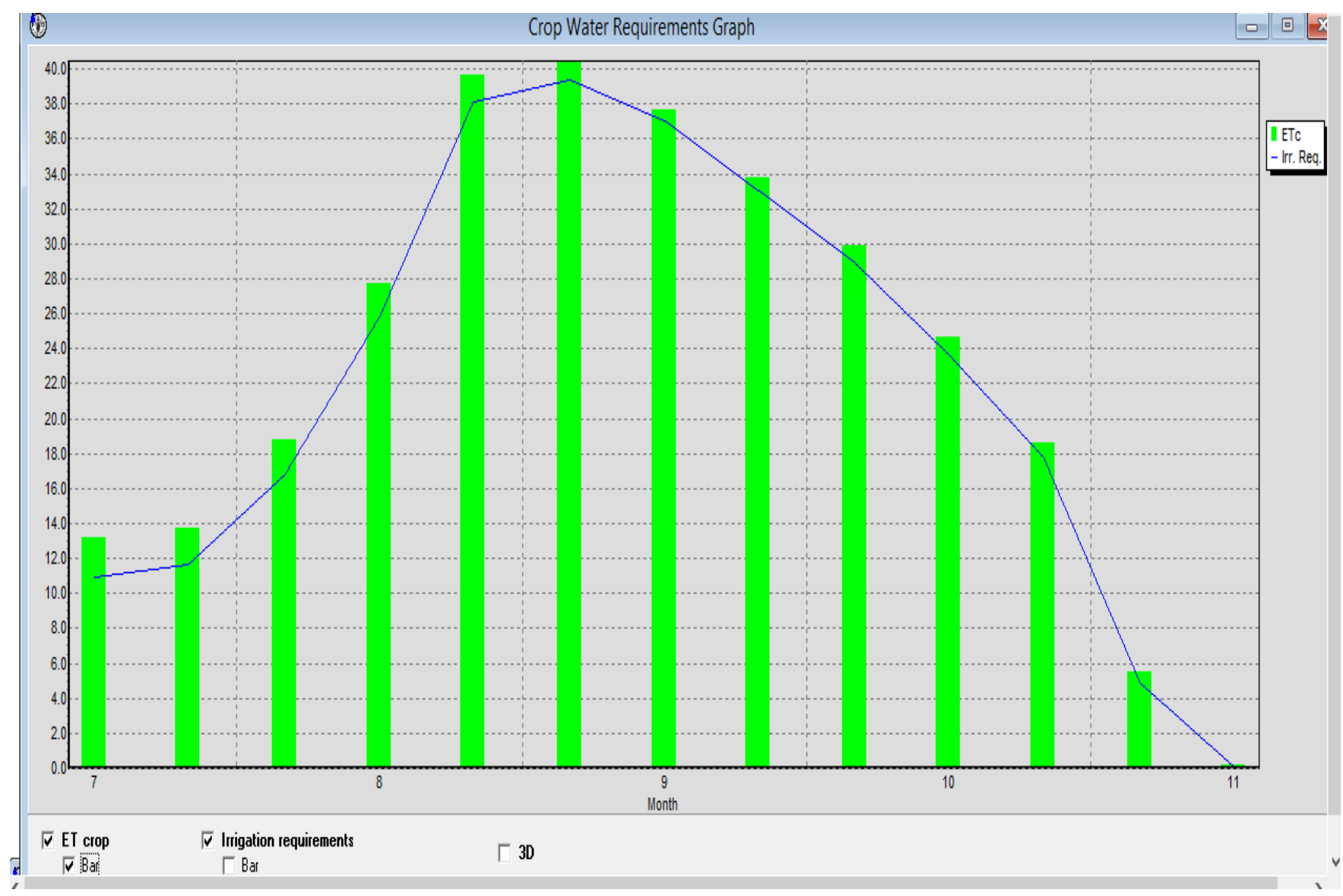


Fig.6 Irrigation scheduling without water stress

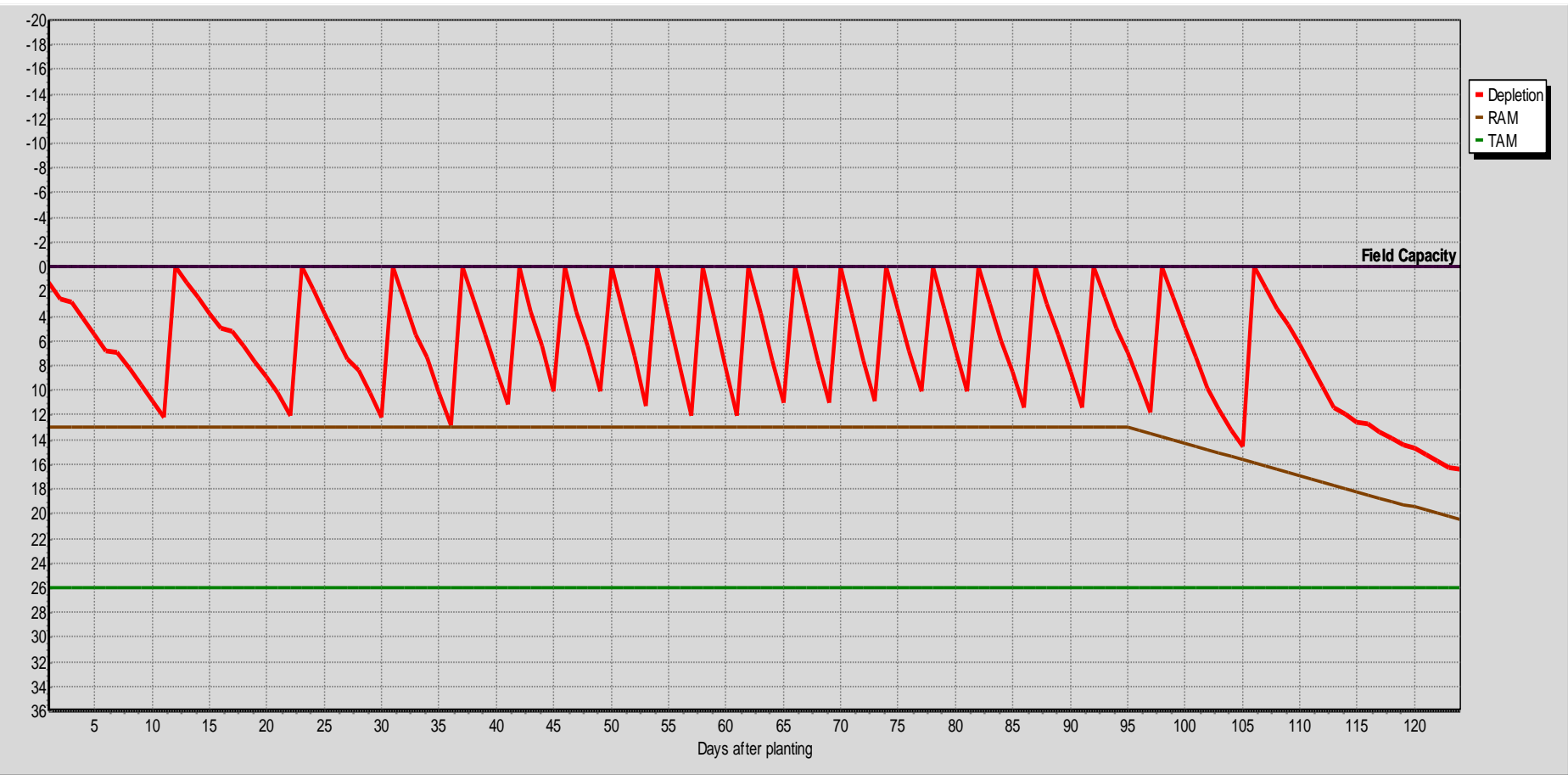

Fig.7 Irrigation scheduling with water stress

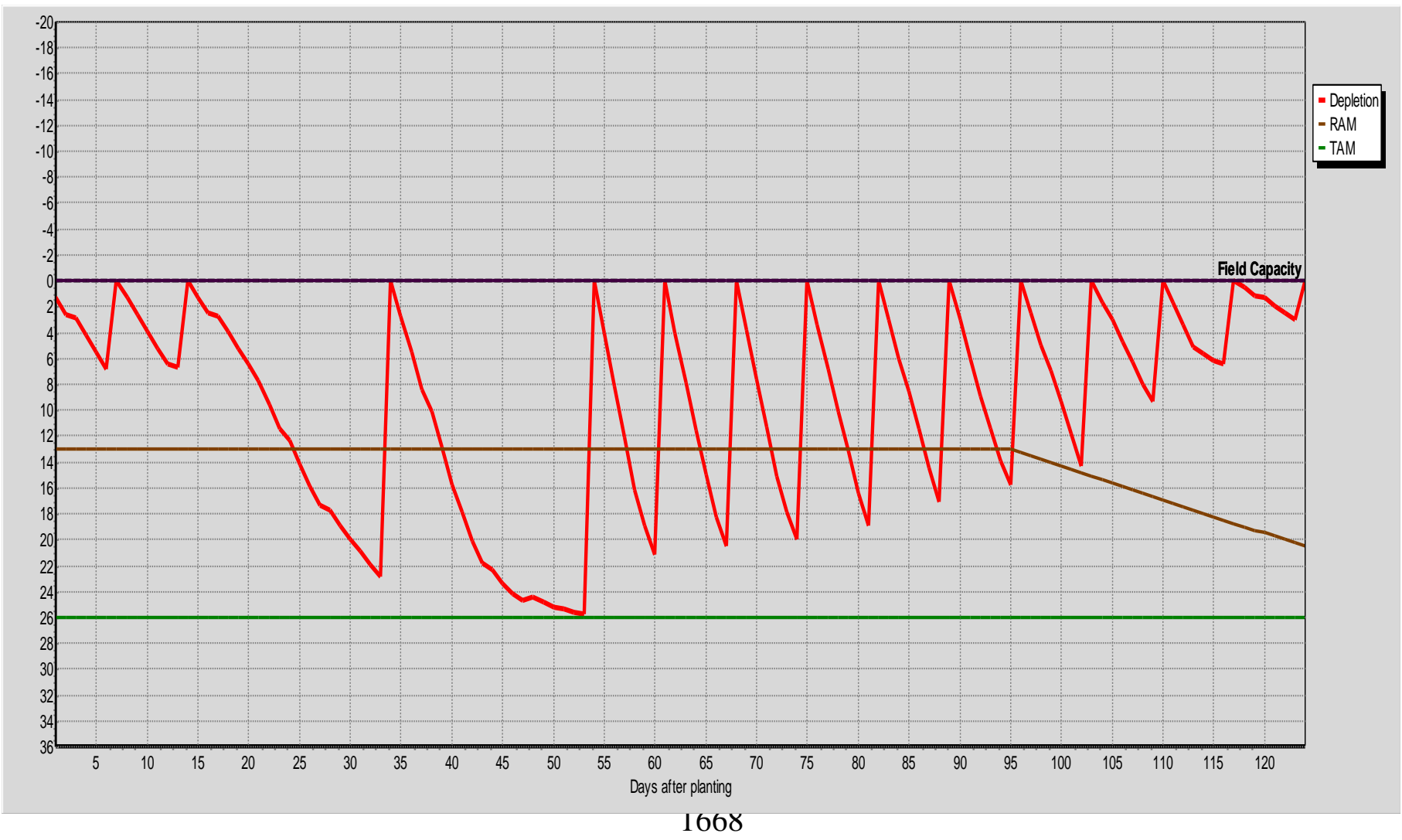


Table 4 shows application to $100 \%$ of field capacity with irrigation at $100 \%$ depletion achieved $70 \%$ of field efficiency where yield reduction was "zero". These met conditions and data for the optimal irrigation treatment (with no stress water applied) (Fig 6). Second step with water stress consisted of application to $100 \%$ of field capacity with Irrigation at fixed interval per stage), where the yield reduction was $25.10 \%$. This was achieved by adapting fixed interval per stage (Interval in days: initial 7, development 7 , mid 20, late 7) (Fig. 7).

The adequacy of water resources has been studied in detail to enable development of net irrigation requirements for maize crop. Proper and optimal scheduling of irrigation using CROPWAT 8.0 enabled the efficient water use to $70 \%$.The crop water requirement for maize crop was found to be $304 \mathrm{~mm}$ and irrigation requirement $288.2 \mathrm{~mm}$. Yield reduction at critical depletion, irrigate at a given ET crop reduction per stage and irrigate at fixed interval per stage at $70 \%$ field efficiency was found to be $0 \%, 14.9 \%$ and $25.1 \%$ respectively. Also yield reduction at no water stress and at water stress was found to be $0 \%$ and $26.80 \%$ respectively.

\section{References}

Adriana, S. M., (2004) "description of the CROPWAT model 7-21

Andriana and Cuculeana (1999) FAO Irrigation Water Requirements guidelines paper.

Dechmi F, Playa 'n E, Faci J.M, Tejero M and Bercero A (2003). Analysis of an irrigation district in north-eastern Spain II. Irrigation evaluation, simulation and scheduling. Agric Water Manag 61: 93 109.

FAO (Food and Agriculture Organization).
CROPWAT Software, Food and Agriculture Organization, Land and Water Division; Available at: 2009. http://www.fao.org/nr/water/infores_dat abases_cropwat.html,

FAO. Guidelines for predicting crop water requirements by $\mathrm{J}$ Doorenbos and W.O. Pruitt. FAO Irrigation and Drainage. 1977, 24.

FAOClimwat for Cropwat, a climatic database for irrigation planning and management by M. Smith. FAO Irrigation and Drainage, 1993, 49.

George, B., Shende, S., and Raghuwanshi, N. (2000). Development and testing of an irrigation scheduling model. Agricultural Water Management, 46(2), 121-136.

Gouranga Kar, Verma HN (2005) Climatic water balance, probable rainfall, rice crop water requirements and cold period in AER 12.0 in India. Agric Water Manag 72: 15-32.

Gouranga Kar, Verma HN (2005) Climatic water balance, probable rainfall, rice crop water requirements and cold period in AER 12.0 in India. Agric Water Manag 72: 15-32.

Gowda T.P, Manjunaththa S.B, Yogesh T.C and Satyareddim S.A (2013). Study on Water Requirement of Maize (Zea mays L.) using CROPWAT Model in Northern Transitional Zone of Karnataka. Journal of Environmental Science, Computer Science and Engineering and Technology 2(1): 105113.

Hess, T., 2005. Crop water requirements. Water and Agriculture, WCA infoNET.

Kuo S, Ho S and Liu C (2006). Estimation irrigation water requirements with derived crop coefficients for upland and paddy crops in ChiaNan Irrigation Association, Taiwan. Agric Water 
Manag 82: 433-451.

Martyniak L, Dabrowska-Zielinska K and Szymczyk R (2006). Validation of satellite-derived soil-vegetation indices for prognosis of spring cereals yield reduction under drought conditionsCase study from central-western Poland. Advances in Space Research 8: 1-6

Smith M. Cropwat: A computer program for irrigation planning and management. FAO Irrigation and Drainage, 1992, 46
Smith, M. (1991). FAO Methodologies on Crop Water Use and Crop Water Productivity. Water, 18, 1-18. [4]

Smith, Martin (1991). "CROPWAT: Manual and Guidelines." FAO of UN, Rome.

Zhiming F, Dengwei $\mathrm{L}$ and Yuehong $\mathrm{Z}$ (2007). Water Requirements and Irrigation Scheduling of Spring Maize Using GIS and CROPWAT model in Beijing-Tianjin-Hebei Region. Chinese Geographical Science 17(1): 56-63.

\section{How to cite this article:}

Shakeel Ahmad Bhat, B.A. Pandit, J.N. Khan, R. Kumar and Rehana Jan. 2017. Water Requirements and Irrigation Scheduling of Maize Crop using CROPWAT Model. Int.J.Curr.Microbiol.App.Sci. 6(11): 1662-1670. doi: https://doi.org/10.20546/ijcmas.2017.611.199 